Society for the Anthropology of Work • Policing and Labor

\title{
Antiracism as Police Work: A Case from the Black Mediterranean
}

\section{P. Khalil Saucier}

Published on: Dec 01, 2020

DOI: $10.21428 / 1 \mathrm{~d} 6$ be30e.fcc36882

License: Creative Commons Attribution 4.0 International License (CC-BY 4.0). 
Policing is not what we think it is.

-Tryon Woods

Migrant shipwrecks and drownings in the Mediterreanean Sea are ubiquitous concretions. And while Black Lives Matter protests and sympathies circulate the globe, the number of Black African lives lost at sea continues to accumulate. The so-called migrant crisis in the Euro-Mediterranean basin is often understood through a political economic analysis in relation to the state, with a focus on labor, work, and class division in general and police work more specifically. In this light, the migration crisis is the result of subjecting human mobility-in this case, out of Africa-to state power and the forces of capitalist accumulation, which include but are not limited to supply chains, development projects, labor agreements, methods of neocolonial extraction, immigration policies, border policing, and consumption practices.

This crisis is also understood as the result of escalating anti-immigrant racism and nativism throughout Europe, but with little to no attention paid to antiblackness. While there is increasing interest in processes of racialization whereby race is understood to be reproduced in the present, blackness often becomes merely a historical referent and/or empirical supplement rather than the source and sequence of modernity. To this end, I suggest that we tarry with presuppositions about police work in the Mediterranean, in order to illustrate that the political and economic logics (of justice, democracy, rights, etc.) used to understand the migrant crisis are organized by an antiblack culture of politics (see also Vargas 2018; Woods 2019).

\section{Normative Police Work}

The backdrop of what I will call normative police work is often understood in physical, spatial, and institutional terms, rather than as something that is also epistemological and axiological. Put slightly differently, police work is understood as an activity or series of activities that uphold the law, rather than as a regime of social organization. However, placing a premium on normative forms of policing in the Mediterreanean generates profound analytical blind spots that undermine black freedom and selfpossession (Saucier and Woods 2016, forthcoming).

Conventional forms of police work in the Mediterreanean are said to encompass sophisticated technologies of speculation and securitization (e.g., the European border surveillance system known as EUROSUR) and procurement of biometric data by the 
EURODAC database, as well as the search and rescue operations conducted by neocolonial operatives such as the Euro-Mediterranean Partnership and the Union for the Mediterranean. Yet little attention is paid to the ways in which police work is conducted outside, or beyond, statist technologies of securitization and surveillance. As a result, the police and, by extension, police work is too often understood as constitutive of the state and only the state: in this context, work conducted by state agents within the maritime borders of the Mediterranean. In other words, it is often assumed that states have dominion over police work and that police work helps execute national and international laws. Since police work is seen as simply an auxiliary of the state, there is an overemphasis on the juridical and political aspects of police work at the expense of the putatively superfluous cultural aspects of police powers (cf. De Genova 2017; Seigel 2018). As Tryon Woods (2019: 10) avers, the statist policing apparatus is "secondary to the police power of civil society from which the criminal justice apparatus derives its power." Technologies of securitization, understood as police work, are really just a manifestation of the power that helps to reinforce the structure of antiblackness.

Thus, I would argue that while conventional ideas and forms of police work help to maintain the social through the use of force, axiological and epistemological claims also maintain the social contract. It is not that a political economy of police work is incorrect, but it is insufficient. It correctly understands the conditions that make aquatic suffering and death a reality, but it does so at the expense of a robust understanding of police power. In short, police work does not account for police power. Therefore, when antiracists focus on the police as opposed to police power, they reaffirm the dominant social order and its structuring of humanity by conceptualizing race as an ontical designation, rather than an ontological position that is foundational to modern Europe and the world.

On reflection, I am suggesting that migration out of Africa is always already violent and not the result of a failed state or some new predatory stage of racial capitalism, but rather a technology of ontological policing that fuses itself to the body politic of "the human" (Wynter 2003). The figure I refer to as the Black African-comes into being as the ground on which modernity is constructed, whose blackness has no ontological ground on which to assert axiological value and thus is not a signatory to the social contract. In other words, blackness is antagonistic to the social and embodies the limits of the human. 
It is my belief that antiracism underwrites the body politic of the human by way of conceptual aphasia, an ideological speechlessness about the foundational violence on which the structure of humanity is built (Saucier and Woods 2016). ${ }^{1}$ In doing so, it highlights how police work is also an immanent feature of civil society. That is, police work does more than catch "criminals" broadly construed. It creates and safeguards paradigmatic borders; it safeguards humanity itself. Thus, antiracists may be said to perform boundary work at the boundary of the distinction between human and nonhuman.

\section{Antiracism as Police Work}

Police work elicits forms of antiracism that, as both ideology and practice, are predicated on certain axiological and epistemological formations. More specifically, conventional forms of police work and their repudiation, in this case through antiracist organizing in the Mediterranean, resuscitate an investment in the human as an allencompassing and nonracial category for thought and praxis. Antiracists assert a false universalism (claiming that all sentient beings are human) with no attention given to the psychic function that the Black African plays within the discursive terrain of the Western imaginary. To prioritize the ways in which police work impacts political and economic systems too often presupposes a version of the human that is singular and falsely universal. In doing so, antiracist work is itself a form of police work in that it fails to recognize and engage with the foundational and structural aspects of antiblackness, therefore upholding the basic structure of antiblackness that creates the migrant problem in the first place.

All police work is inherently organized around the logic by which blackness equals humanity's absence. In leaving intact this structure of humanity, one also leaves the structural capacity to inflict physical and epistemological violence. That is, ignoring the structural logic of police work inaugurated in the Euro-Mediterranean basin centuries ago allows for the social fabric to be maintained, albeit altered and reformed. Any gesture toward reforming or improving aquatic police practices fortifies the problem, the cultural formation of Western society to which antiracism is sutured. In other words, "antiracism bears within its epistemic...fold the imprint of antiblackness, and as such, critical thought for freedom cannot remain at the level of empirical, experiential, or material reality alone” (Woods 2019: 181). In the end, antiracism is an appurtenance of police power, albeit with a progressive flair.

Too often, antiracism sees the problem in terms of the punitive ways that the state and its various actors punish migrants for breaking the law, namely by transgressing the 
border illegally. For example, antracist academic and activists advocate for greater acknowledgement of the militarization of police work, in hopes of transforming Europe for the better. While no doubt an encouraging development, such focus still ignores deeper structural logics. Part of the problem in discussing police work in this way is the elision of its connection to blackness, which prevents us from seeing the longue durée of racial slavery. There is the tendency to see police work in this region as becoming increasingly militarized, with any and all tragedies the result of bad policing or too much policing. But any look into the longue durée of racial slavery would suggest that the police have always been militarized when working in relation to those structurally positioned as black.

If we think of police work in Mediterranean, it is clear that the production of knowledge should not be detached from questions about the structure of humanity. Although I do not want to deny the usefulness of a political economy of police work, I contend that this strategy alone is insufficient and that it relies on a false universalism that overlooks inherent racial antagonisms. In this sense, all police work, as derivative of police power, helps to form a methodology for social organization, while understanding police work as also axiological and epistemological can help us to better understand the operation of racism and race in the region. In short, privileging the state at the expense of the cultural is tantamount to denying antiblackness or, at the very least, augmenting it.

\section{Conclusion}

A few years ago, I was invited to take part in a workshop on the migrant crisis in Europe, an experience that unfolded in a way that was undoubtedly predictable but nonetheless, to me, surprising. As I did my best to center my analysis on black suffering beyond exploitation and alienation, my ideas were embraced only to be discarded. As is all too common, there was ideological endorsement and consensus but then, in practice, a turning away from the centrality of antiblackness. Antiracist scholars and activists often incorporate blackness in order to construct an alibi for dismissing it in favor of a falsely universalist solidarity with non-Black migrants. As the

anthropologist João Costa Vargas (2016: 63) asks: "Why is it that, when black suffering and death are momentarily centered, they are almost always displaced by conversations that recenter the experiences of nonblacks?"

The answer is self-evident if we extend our understanding of police work. In doing so, black self-possession would literally undo the world as we know it, for the Black African-would be free to develop their own universality beyond the structure of 
humanity that is too often relied on by antiracists. What antiracists fear is that, without the Black African, they will be nothing! There can be no human without its absence. So police work continues and continues.

\section{Note}

1. The definition of antiracism is, of course, contested by ideologies that range from liberal progressivism to radical resistance.

\section{Preview Image}

Photo by $\underline{\text { Chris Henry. }}$

\section{References}

De Genova, Nicholas, ed. 2017. The Borders of "Europe": Autonomy of Migration, Tactics of Bordering. Durham, NC: Duke University Press.

Saucier, P. Khalil, and Tryon P. Woods, eds. 2016. Conceptual Aphasia in Black: Displacing Racial Formation. Lanham, MD: Lexington Books. . Forthcoming. Ex Aqua: The Black Mediterranean and the Politics of Policing. Manchester, UK: Manchester University Press.

Seigel, Micol. 2018. Violence Work: State Power and the Limits of Police. Durham, NC: Duke University Press.

Vargas, João Costa. 2016. “Can the Line Move? Antiblackness and a Diasporic Logic of Forced Social Epidermalization." In Critical Ethnic Studies: A Reader, edited by the Critical Ethnic Studies Editorial Collective, 63-91. Durham, NC: Duke University Press. . 2018. The Denial of Antiblackness: Multiracial Redemption and Black Suffering. Minneapolis: University of Minnesota Press.

Woods, Tryon P. 2019. Blackhood Against the Police Power: Punishment and Disavowal in the "Post-Racial" Era. Lansing: Michigan State University Press.

Wynter, Sylvia. 2003. “Unsettling the Coloniality of Being/Power/Truth/Freedom: Toward the Human, After Man, Its Overrepresentation-An Argument." CR: The New Centennial Review 3(3): 257-337. 